\title{
INDUSTRIAL GAS TURBINE ENGINE OFF-DESIGN PERFORMANCE IMPROVEMENT CONTROLLING COOLING AIR FLOW
}

The modern gas turbine engine has been used in current power generation industry for almost half a century. They are designed to operate with the best efficiency during normal operating conditions and at specific operating points. However, due to power grid demands, different ambient temperatures, fuel types, relative humidity and driven equipment speed the gas turbine units have to work today on partial load too, which can affect the hot gas path condition and life expectancy. At these off-design conditions, gas turbine's efficiency and life deterioration rate might significantly deviate from the design specifications. In this paper, a digital twin concept for gas turbine unit off-design perfor-

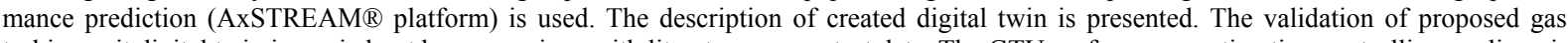
turbine unit digital twin is carried out by comparison with literature source test data. The GTU performance estimation controlling cooling air at part load modes using digital twin was performed.

Key words: gas turbine unit digital twin, gas turbine unit, off-design mode, power control, cooling system control, efficiency improvement.

\section{Л. И. МОРОЗ, М. В. БУРЛАКА, В. С. БАРАННИК \\ УВЕЛИЧЕНИЕ ПРОИЗВОДИТЕЛЬНОСТИ ПРОМЫШЛЕННОГО ГАЗОТУРБИННОГО ДВИГАТЕЛЯ ПУТЕМ РЕГУЛИРОВАНИЯ РАСХОДА ОХЛАЖДАЮЩЕГО ВОЗДУХА}

\begin{abstract}
Современный газотурбинный двигатель используется в энергетике уже почти полвека. Они предназначены для работы с максимальной эффективностью при нормальных рабочих условиях и в конкретных рабочих точках совместной работы турбины и компрессора. Тем не менее, из-за требований электросети, изменения температуры окружающей среды, типа топлива, относительной влажности или частоты вращения приводного устройства, газотурбинные установки вынуждены сегодня работать при частичной нагрузке, что может повлиять на состояние проточной части турбины и продолжительность ее жизни. При этих внепроектных условиях эффективность газовой турбины и коэффициент износа могут значительно отличаться от проектных спецификаций. В данной статье используется концепция цифрового двойника объекта для прогнозирования производительности турбоагрегата на внепроектных режимах (платформа AxSTREAM®). Представлено описание созданного цифрового двойника. Валидация предлагаемого цифрового двойника газотурбинной установки осуществляется путем сравнения с данными испытаний приведенными в источниках литературы. Была выполнена оценка производительности ГТУ, при управлении расходом охлаждающего воздуха на режимах частичной нагрузки с использованием цифрового двойника.

Ключевые слова: цифровой двойник газотурбинного агрегата, газотурбинный агрегат, режим внепроектной работы, управление мощностью, управление системой охлаждения, повышение эффективности.
\end{abstract}

\section{Л. І. МОРОЗ, М. В. БУРЛАКА, В. С. БАРАННІК \\ ЗБІЛЬШЕННЯ ПРОДУКТИВНОСТІ ПРОМИСЛОВОГО ГАЗОТУРБІННОГО ДВИГУНА ШЛЯХОМ РЕГУЛЮВАННЯ ВИТРАТИ ОХОЛОДЖУЮЧОГО ПОВІТРЯ}

Сучасний газотурбінний двигун використовується в енергетиці вже майже півстоліття. Вони призначені для роботи 3 максимальною ефективністю при нормальних робочих умовах і в конкретних робочих точках спільної роботи турбіни і компресора. Проте, через вимоги електромережі, зміни температури навколишнього середовища, типу палива, відносної вологості або частоти обертання приводного пристрою, газотурбінні установки змушені сьогодні працювати при частковому навантаженні, що може вплинути на стан проточної частини турбіни і тривалість ï життя. При цих внепроектних умовах ефективність газової турбіни і коефіцієнт зносу можуть значно відрізнятися від проектних специфікацій. У даній статті використовується концепція цифрового двійника об'єкта для прогнозування продуктивності турбоагрегату на позапроектних режимах (платформа AxSTREAM®). Представлено опис створеного цифрового двійника. Валідація запропонованого цифрового двійника газотурбінної установки здійснюється шляхом порівняння з даними випробувань наведеними в джерелах інформації. Була виконана оцінка продуктивності ГТУ, при регулюванні витрати охолоджуючого повітря на режимах часткового навантаження з використанням цифрового двійника.

Ключові слова: цифровий двійник газотурбінного агрегату, газотурбінний агрегат, режим внепроектної роботи, управління потужністю, управління системою охолодження, підвищення ефективності.

\section{Introduction}

Gas turbines are widely used all over the world. The same GTU frame could be installed in arctic or desert regions providing significantly different environmental conditions. But even little change of boundary conditions causes a significant influence on integral characteristics and reliability of the engine. It is well known, that ambient temperature elevation leads to unit efficiency and power deterioration and vice versa when the turbine inlet temperature is fixed $[1,2]$.
There are two main reasons for GTU off-design operation:

- Environment-induced off-design.

- Grid demands or driven device induced offdesign.

Environment-induced off-design is not desired in terms of driven equipment. It is usually a subject to mitigation utilizing the approaches that help to save fixed GTU power with ambient temperature rise [3]:

- Chiller application at compressor inlet.

- Water evaporation at compressor inlet.

- Humid air/steam injection to combustor

(C) L. Moroz, M. Burlaka, V. Barannik, 2018 
chamber.

The off-design induced by grid demands or driven device can be achieved in several ways [4]. In the current paper, the part-load modes were carried out by turbine inlet temperature reduction. The reduction of temperature is carried out by the decline of injected fuel MFR in the combustor. The compressor inlet MFR, in this case, is almost unaltered and equal to the MFR at design mode.

One of the crucial aspects in off-design performance estimation is a determination of joint operation point of turbine and compressor to check if GTU would reliably operate avoiding any excessive temperatures of turbine blades and surge zones of the compressor and produce a certain amount of power.

The overall approach to search joint operation point is a utilization of the turbine and compressor maps (graphical method) [5, 6]. Maps utilization method is pretty simple and in combination with thermodynamic simulation allow calculating of GTU performance in the shortest time. However, the cooling system presence contributes the necessity of determining of additional factors (parameters), which leads to some simplifications and, as a consequence, may lead to inaccuracies, when maps are used. Some of these simplifications are a determination of cooling air mass flow rate (MFR) as a percent from compressor inlet air MFR and simplified GTU components geometry consideration.

There are many papers devoted to an accurate offdesign performance calculation without maps utilization $[7,8]$. However, their utilization is timeconsuming.

Therefore the methods that allow accounting for advantages of iteration maps method (relatively short time of calculation) with the $1 \mathrm{D}$ calculation of compressor, turbine and cooling system are of interest. The automation of off-design GTU parameters search process makes possible excluding errors related to transferring of large amounts of data for multiple variables.

Simulation of cooled GTU requires a utilization of various $0 \mathrm{D}, 1 \mathrm{D}, 2 \mathrm{D}$ and $3 \mathrm{D}$ models for calculation of GTU components (compressor, turbine, combustor, cooling system etc.), the presence of efficient data transfer between the models and ability to incorporate custom models, and use logical operations and perform optimizations. The complex of the mentioned tools, methods, models, scripts connected in a logical sequence is essentially a digital twin of gas turbine unit (GTUDT). The development and validation of such a GTUDT are presented in this paper.

The digital twin capabilities are especially interesting for optimization tasks. By the authors, the performance augmentation of GTU using developed digital twin by cooling air MFR control is performed.

\section{Nomenclature}

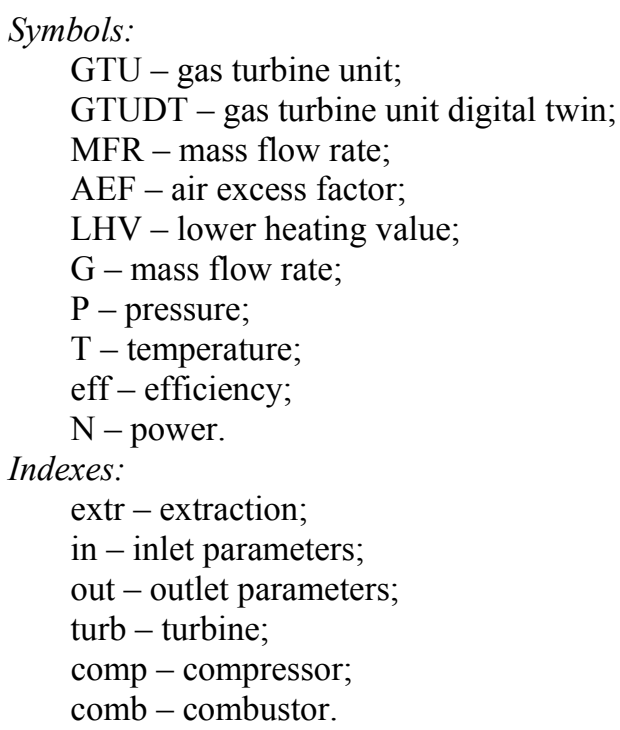

\section{GTU prototype for GTUDT}

The 166 MW single shaft power generation stationary GTU was selected as a prototype, the digital twin will be developed for.

In the scope of this study, it was decided to limit the number of components and systems to be included in digital twin: compressor, combustor, turbine and cooling system (Figure 1). The thermo-structural analysis was not considered in this paper. However, it is planned to include it and expand the number of considered systems in future studies.

The main parameters of GTU prototype are presented in Table 1. Shaft rotational speed is constant for every off-design mode and equals the design mode.

The compressor is 17 stage machine with IGV and three extractions to cooling system: after nozzle of the $11^{\text {th }}$ stage, after rotor of $16^{\text {th }}$ stage and at compressor outlet.

Turbine is a three-stage axial machine with 14 cooling inductions and cooled duct at the turbine inlet.

Cooling system (Figure 2) is presented by three extractions in compressor part, which then divided on 14 cooling flows inducted to blades leading edges, trailing edges, tip, hub and shroud of turbine flow path.

The combustor is calculated by thermodynamic equations. Based on energy balance equations (1)-(4) the fuel MFR was received. Methane was used as a fuel.

$$
I_{\text {in_turb }}=f\left(P_{\text {turb_in }}, T_{\text {turb_in }}, A E F\right),
$$

where $I_{\text {turb_in }}$ - turbine inlet enthalpy;

$P_{\text {turb_in }}$ - turbine inlet pressure;

$T_{\text {turb in }}$ - turbine inlet temperature;

$A E F$ - air excess factor. 
Table 1 - GTU design characteristics

\begin{tabular}{|c|c|c|}
\hline Parameters & Units & Values \\
\hline Tin & $\mathrm{K}$ & 288.15 \\
\hline Pin & $\mathrm{kPa}$ & 101.32 \\
\hline Gin & $\mathrm{kg} / \mathrm{s}$ & 401.84 \\
\hline Pout & $\mathrm{kPa}$ & 1315.0 \\
\hline Tout & $\mathrm{K}$ & 625.85 \\
\hline Gextr & $\mathrm{kg} / \mathrm{s}$ & 26.31 \\
\hline eff & - & 0.9146 \\
\hline $\mathrm{N}$ & $\mathrm{MW}$ & 137.17 \\
\hline \multicolumn{3}{|c|}{ Combustor } \\
\hline Gin & $\mathrm{kg} / \mathrm{s}$ & 375.53 \\
\hline Gfuel & $\mathrm{kg} / \mathrm{s}$ & 9.009 \\
\hline AEF & - & 2.41 \\
\hline \multicolumn{3}{|c|}{ Turbine } \\
\hline Pin & $\mathrm{kPa}$ & 1249.25 \\
\hline Tin & $\mathrm{K}$ & 1550 \\
\hline Gout & $\mathrm{kg} / \mathrm{s}$ & 384.51 \\
\hline Tout & $\mathrm{K}$ & 901.62 \\
\hline eff & - & 0.9459 \\
\hline $\mathrm{N}$ & $\mathrm{MW}$ & 303.67 \\
\hline \multicolumn{3}{|c|}{} \\
\hline
\end{tabular}

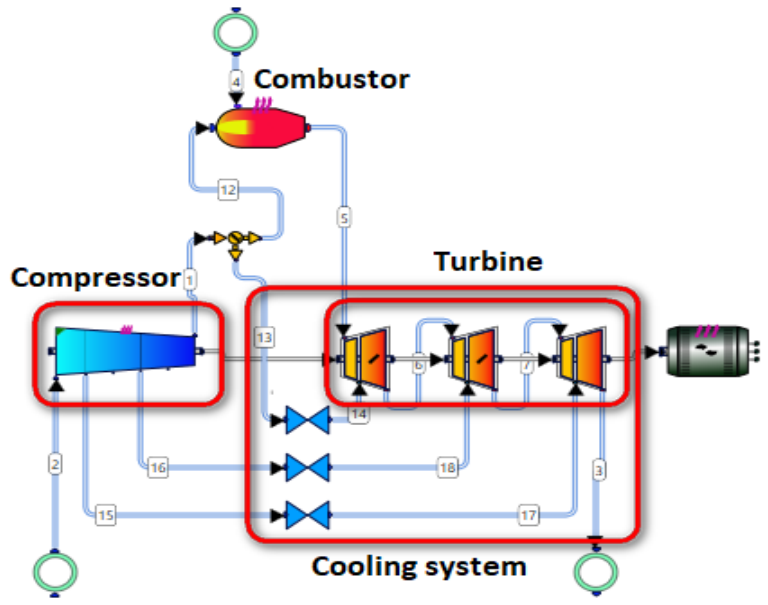

Fig. 1 - Gas turbine unit scheme

$$
G_{\text {fuel }}=\frac{G_{\text {comb_out }} I_{\text {turb_in }}-G_{\text {comp_out }} I_{\text {compr_out }}}{L H V},
$$

where $G_{f u e l}-$ fuel MFR;

$G_{\text {comb_out }}-$ combustor outlet MFR;

$G_{\text {comp_out }}-$ compressor outlet MFR;

$I_{\text {comp out }}$ - compressor outlet enthalpy;

$L H \bar{V}$ - lower heating value.

$$
\begin{gathered}
G_{\text {comb_out }}=G_{\text {comp_out }}+G_{\text {fuel }}, \\
A E F=\frac{G_{\text {comb_out }}}{G_{\text {fuel }} I_{0}},
\end{gathered}
$$

where $I_{0}$ - stoichiometric air-fuel ratio.

$\mathrm{AEF}$ in the (1) is used for determination of combustor products composition that has a significant influence on enthalpy value determined for specified pressure and temperature.

The combustor outlet MFR in the first iteration was set as

$$
G_{\text {comb_out }}=G_{\text {compr_out }},
$$

The initial guess for air excess factor was arbitrarily selected. The pressure drop at combustor was equal 0.05 for all calculations.

\section{Loss models for off-design performance prediction}

Craig and Cox loss model was utilized for prediction of profile losses of the turbine nozzles and blades at the design and off-design modes. The model is empirical and based on experimental data obtained on numerous blade profiles. The authors of the loss model stated that no systematic or major discrepancies have been found in an analysis of over fifty turbines and that the most calculated values of overall efficiency being substantially within \pm 1.25 percent of the measured values [10]. Besides, Ning Wei performed a study of different empirical loss models and determined that Craig and Cox loss model is one of the most accurate empirical loss models for relatively large axial turbines [11].

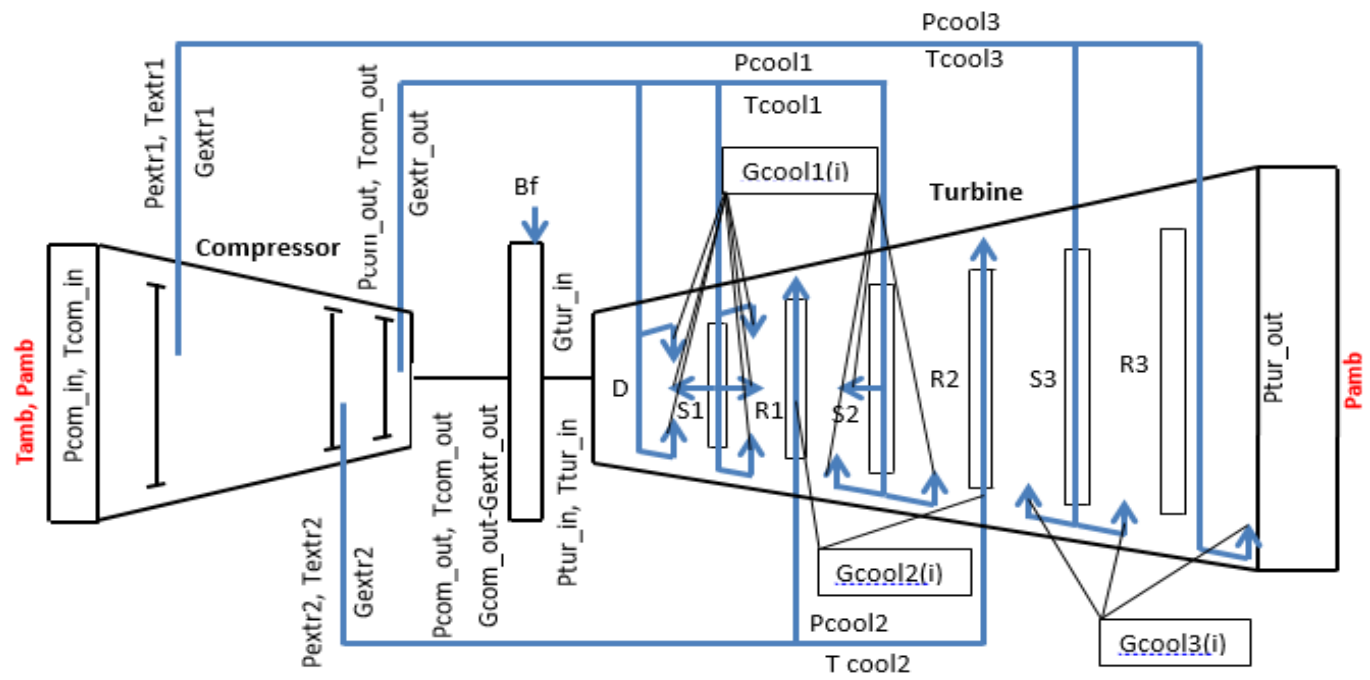

Fig. 2 - Cooling system scheme 


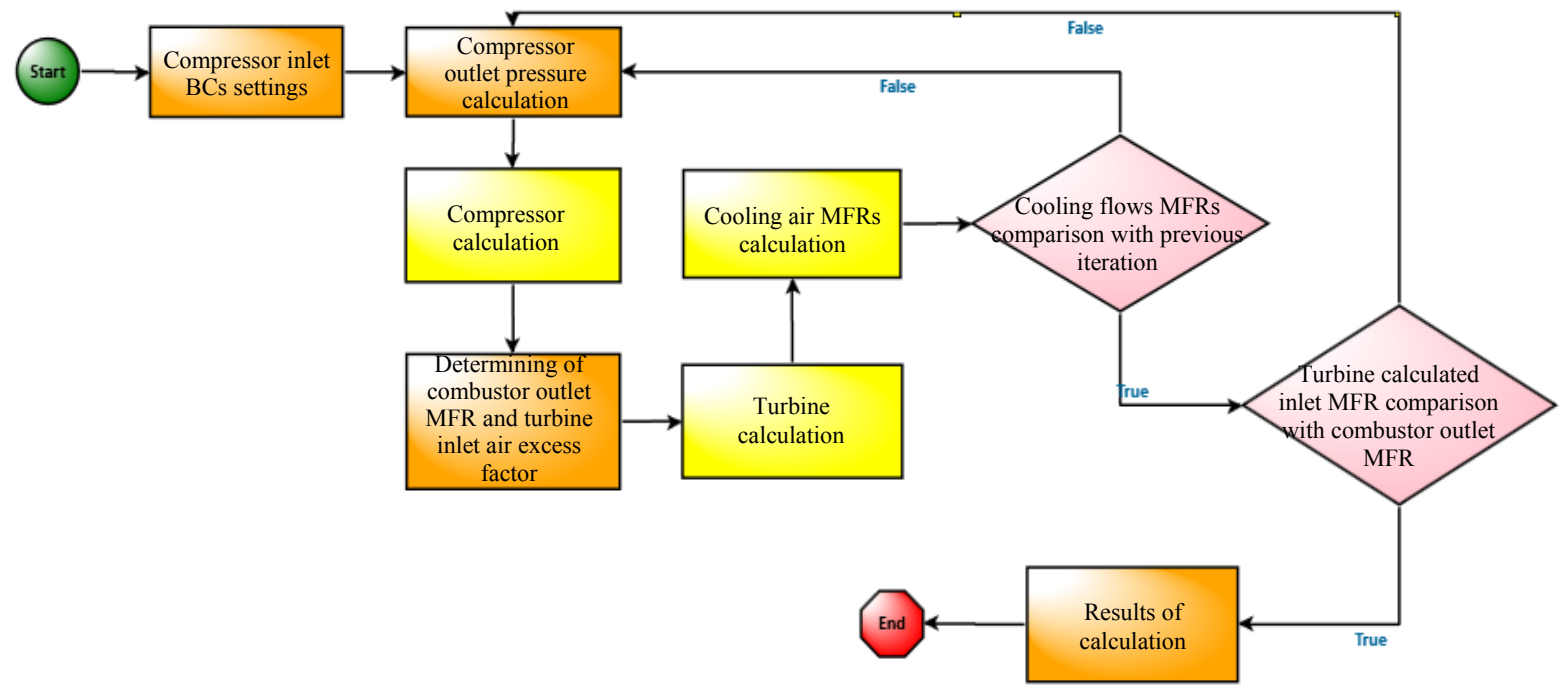

Fig. 3 - Gas turbine digital twin operation flowchart

The profile losses prediction of compressor blades were determined using the Lieblein's test data [12] approximated by Aungier [13]. In [13] author performed the validation of approximated expressions with NACA 10-stage compressor. The validation showed a good approximation of experimental data for each speed line.

The utilization of well-validated loss models for turbine and compressor served as a good foundation for the getting a high accuracy off-design performance prediction of the entire GTU. Besides, the authors performed some validation of the entire algorithm by themselves. The results are presented below in the paper.

\section{The description of the GTUDT}

In this study digital twin is used to simulate the off-design operation of the considered GTU prototype. Turbine inlet temperature was kept constant for each off-design mode.

The scheme of calculation process is presented in Figure 3.

Green circle block is self-explanatory. Orange rectangles represent custom scripts. The scripts were added in order to perform additional calculations not available among off-the-shelf tools. Yellow blocks represent some available computational tool. In particular, for the compressor, it was streamline solver, as well as for turbine. For cooling system, it was hydraulic network 1D numerical solver. Pink diamonds represent conditional statements for process control according to a predefined condition. These blocks allow implementation of loops required to converge required parameter, for example, MFR for each cooling flow. The conditional block could be also used for implementation of alternative paths of the calculation process. Red octahedron is self-explanatory.
The top diamond on the diagram represents the condition of equality of cooling flows MFRs. If balances of the cooling flows mass flow rates extracted from the compressor and inducted to turbine do not correspond, the reassignment of cooling flows MFRs is performed. The equality of turbine inlet MFR and combustor outlet MFR is done by bottom diamond. In this case, the difference in mentioned above MFRs leads to reassigning of turbine inlet pressure.

All described above calculations were performed automatically. Thus, eventually, the capability to simulate off-design performance for any compressor inlet $\mathrm{BCs}$ as in real test facility was achieved.

\section{Validation of GTUDT}

The validation of the developed GTUDT was performed comparing the estimated performance data with real GTU test data [10]. The comparison was performed for the off-design caused by variation of ambient temperature from $+5{ }^{\circ} \mathrm{C}$ to $+30{ }^{\circ} \mathrm{C}$. The ambient pressure and turbine inlet temperature for each offdesign mode were kept constant and equal to the ones at design conditions.

The pressure losses in inlet and exhaust ducts were not taken into account.

The data for power correction factor obtained utilizing the GTUDT and the GTU test data from [10] are presented in Figure 4. Power correction factor is a ratio of power at design mode to power at off-design mode. It is clearly seen that the power correction factor obtained on GTUDT is in good agreement with the power correction factor variation from [10]. This allows concluding that GTUDT performance data results are plausible and that GTUDT can be used for GTU off-design performance data gathering. 


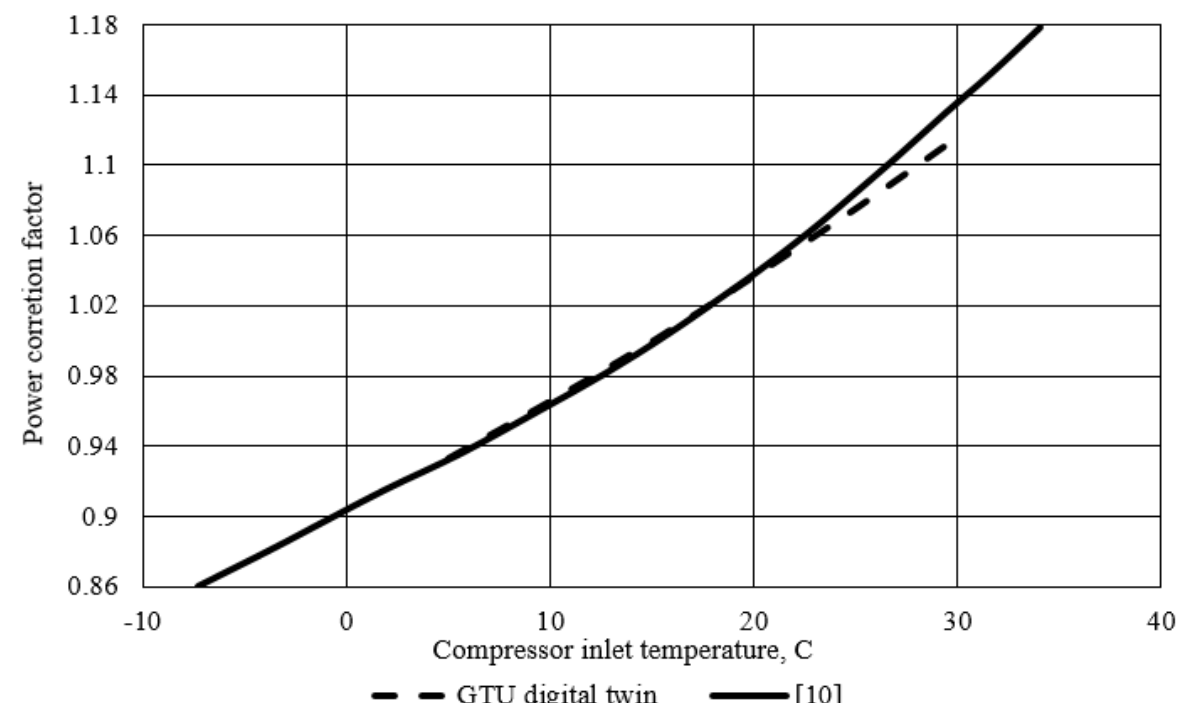

Fig. 4 - Power correction factor vs ambient temperature

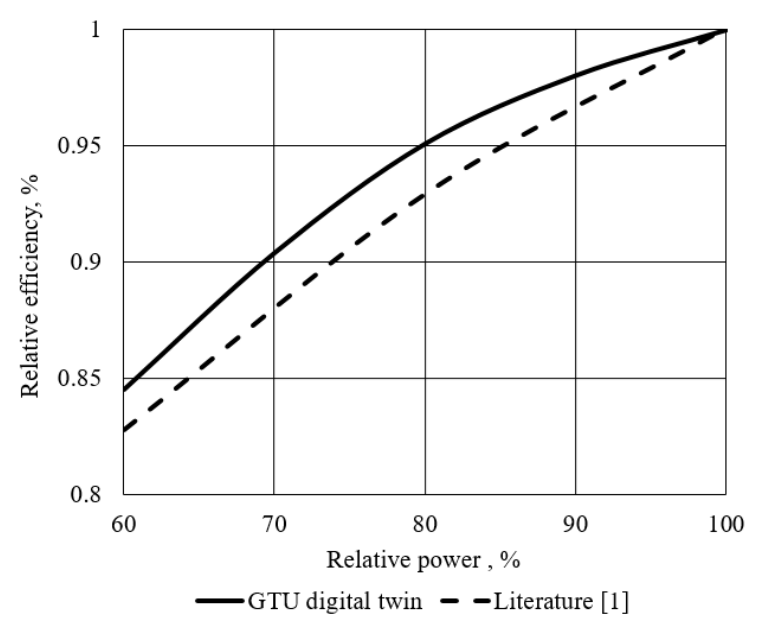

Fig. 5 - Turbine exhaust temperature vs power in relative values

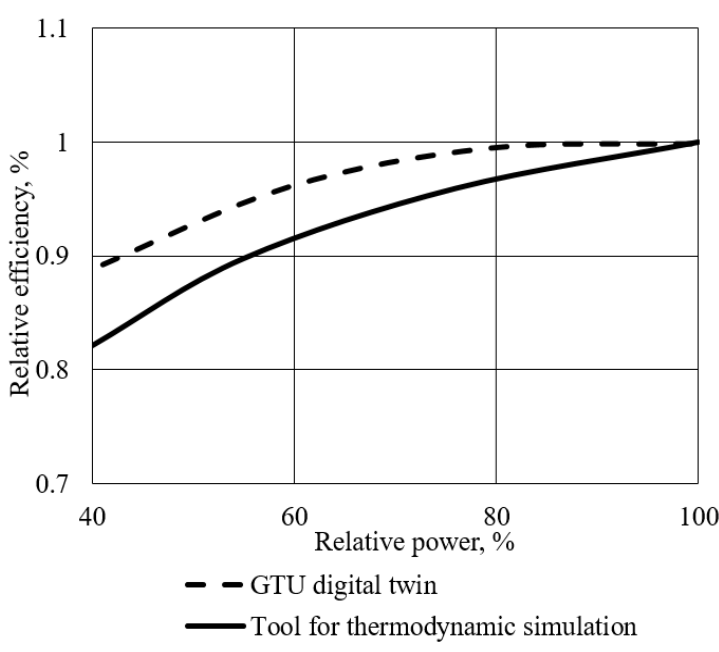

Fig. 6 - The dependency of unit efficiency from power level
Also, the validation of proposed digital twin was performed by comparison the turbine outlet temperature for different power level with generalized test data from [1] (Figure 5). The part loads of GTU are carried out by compressor inlet MFR decreasing.

The comparison of the curves showed that the obtained results are in good agreement with the trend obtained experimentally in [1], demonstrating the correctness of the results obtained on GTU virtual test facility.

\section{Comparison of GTUDT results with heat balance calculation tool results}

The estimation of GTU part load performance was performed utilizing the proposed VTF and utilizing cycle calculation tool with the embedded map for the compressor. The compressor map was preliminarily generated using described above streamline solver. The turbine efficiency was found based on Stodola law.

The comparison of the results is presented in this section. The dependencies of GTU efficiency determined by two mentioned approaches are presented in Figure 8.

Figure 6 shows the GTUDT results in $6 \%$ (in relative values) difference in efficiency value at $40 \%$ of unit power in comparison with results obtained with the conventional thermodynamic solver.

The difference can be explained by that the map was generated for fixed values of cooling flows extractions/inductions taken from design mode, but actually, the cooling flows parameters were varying for different part load modes. Its own portion of contribution into discrepancy value brought the air mass flow rate calculation method in case of map approach. Namely, it was calculated based on the simple pressure drop without taking into account variation of other thermodynamic and kinematic parameters of cool- 
ing flows at extraction/induction slots of compressor/turbine flow paths. The other factor is that the cooling flows are injected into turbine stage in two sections only (upstream and downstream turbine rotor) in map approach. Besides mentioned above, the modeling of the turbine by Stodola law brought some degree of discrepancy into the results in comparison with detailed turbine simulation in streamline solver.

All mentioned above factors allows concluding that the proposed VTF results demonstrate a higher degree of accuracy in comparison with the utilized map-based approach. It should be noted that mapbased approaches can be based on real field data and take into account variation of cooling flows and real compressor/turbine performance and induction/extraction slots parameters. In this case, the fidelity of the results can be rather high too. However, the advantage of VTF is that field data is not required.

\section{GTU performance augmentation by cooling air MFR control}

It is well known that GTU part-load control by turbine inlet temperature envisages a reduction of the turbine inlet temperature to obtain the part-load mode of GTU. Authors of this paper performed simulation of part-load mode of GTUDT (these results are not presented here, but they will be published in ASME Turbo Expo 2018 paper) and determined that the temperature of hot gas can become even less than blades material allowable temperature, but cooling mass flow rate was almost the same as in the design mode. In other words, the cooling flow is simply wasted at deep part load modes. It is obvious to assess the possibility of cooling mass flow rate control in order to adjust it according to the temperature of hot gas and improve the efficiency of GTU at deep off-design modes.

The proposed GTUDT was utilized to perform the assessment. For this, GTUDT cooling system was modified by the addition of control valve to the cooling channel going to first nozzle vane. The first vane required the most significant amount of cooling. Thus the effect from the reduction of cooling flow to the first nozzle has to be pretty significant.

\section{Determining the quantity of cooling air MFR}

There are dependencies in the literary sources that allow approximately calculate the required cooling air MFR for given type of cooling and temperature of the main flow.

In the presented paper the cooling air MFR was determined from [11] (Figure 7).

$$
\bar{G}=G_{\text {cool }} / G_{\text {gas }},
$$

where $\bar{G}$ - relative cooling air MFR;

$G_{\text {cool }}$ - cooling air MFR;

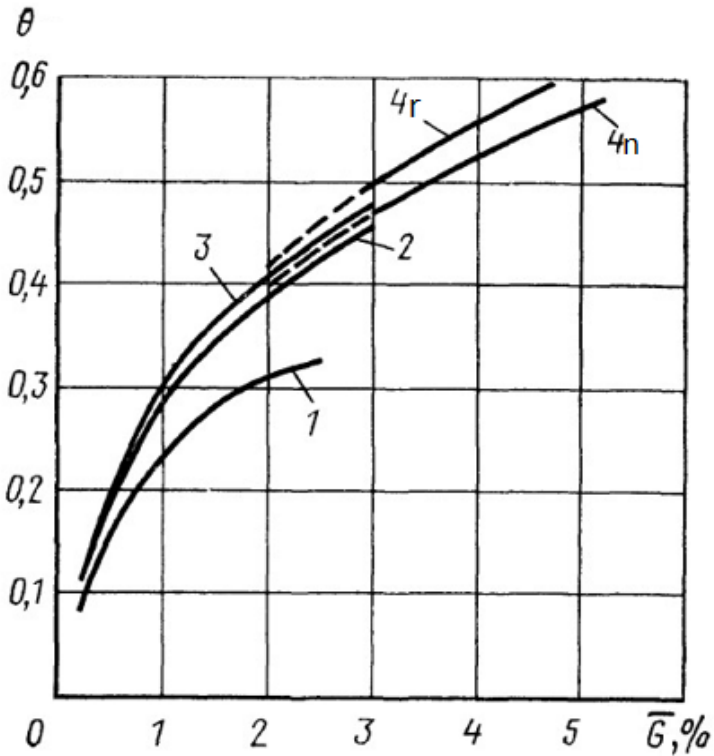

Fig. 7 - Efficiency of different types of air cooling:

1 - blade with radial channels; 2 - blade with the semi-closed cooling system; 3 - deflector blade; $4 n$ - nozzle blade film cooling; $4 r$ - rotor blade film cooling

$G_{\text {gas }}-$ MFR of the main flow.

$$
\theta=\frac{T_{g a s}^{*}-T_{b l}}{T_{g a s}^{*}-T_{c o o l}^{*}},
$$

where $T_{\text {gas }}^{*}$ - total temperature of main flow;

$T_{b l}$ - maximal allowable temperature of blade without cooling;

$T_{\text {cool }}^{*}$ - total temperature of cooling flow.

Since the blade cooling type for presented GTU is film, the necessary cooling MFR was determined by the " $4 n$ " line.

\section{Results of cooling air MFR adjustment}

The effect of cooling air MFR control on VGTU performance for different power levels is presented in comparison with performance without any cooling system control.

The dependency of GTUDT performance for different power level is presented in Figure 8.

As we can see from Figure 8 the efficiency of GTUDT with the controlled cooling system is higher than one of GTUDT with the uncontrolled cooling system. The efficiency increment at $40 \%$ of power is about $3.5 \%$ in relative values, at the $70 \%$, it is about $1 \%$. It should be noticed that cooling air MFR was controlled for first nozzle only. It can be assumed that the cooling air MFR controlling at another flow path elements allows getting even higher efficiency increments. The GTUDT efficiency curve bend between $60 \%$ and $50 \%$ part load modes was caused by the full closure of the first nozzle cooling channel. The rest of 
flow path elements have no control in this study, but GTUDT allows controlling the other cooling system branches either.

The distribution of cooling air MFR at different GTUDT power levels is presented in Figure 9.

It is clearly seen from Figure 9 that the decrement of the cooling air MFR is much more significant for the case of the controlled cooling system. The turbine inlet temperature is less than the maximal allowable temperature of flow path metal in the range of $50 \%-60 \%$ of power.

It should be noticed that presented methodology of cooling system calculation allows defining the flow directions inside the blade, which is possible at some deep part-load modes.

This assessment was not performed in this study. It is planned to include such an analysis and to perform cooling system control simulation at GTUDT part-load modes taking into account possible penetration of hot gas inside the blade and its influence on blade temperature and adjust cooling flow rate accordingly.

The dependency of relative turbine inlet temperature from power level is presented on Figure 10.

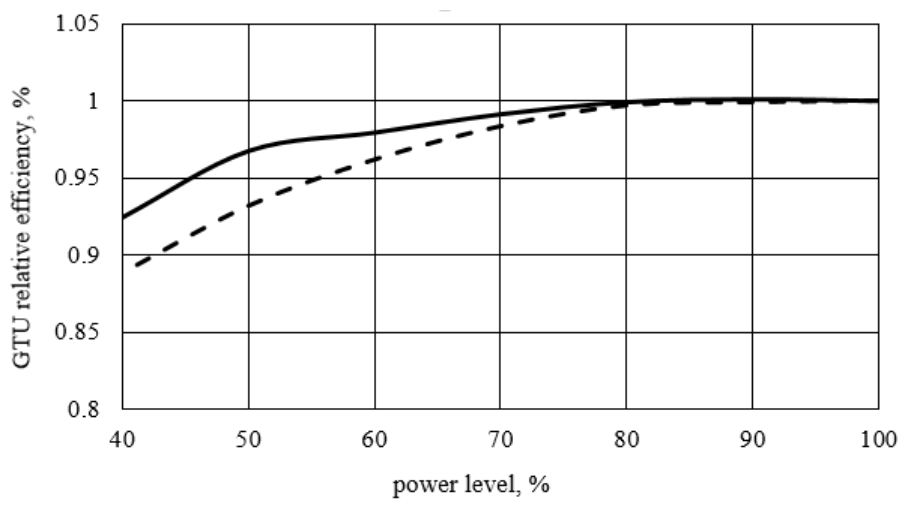

controlled cooling system $\quad$ - - - uncontrolled cooling system

Fig. 8 - Relative GTU efficiency vs GTU power level

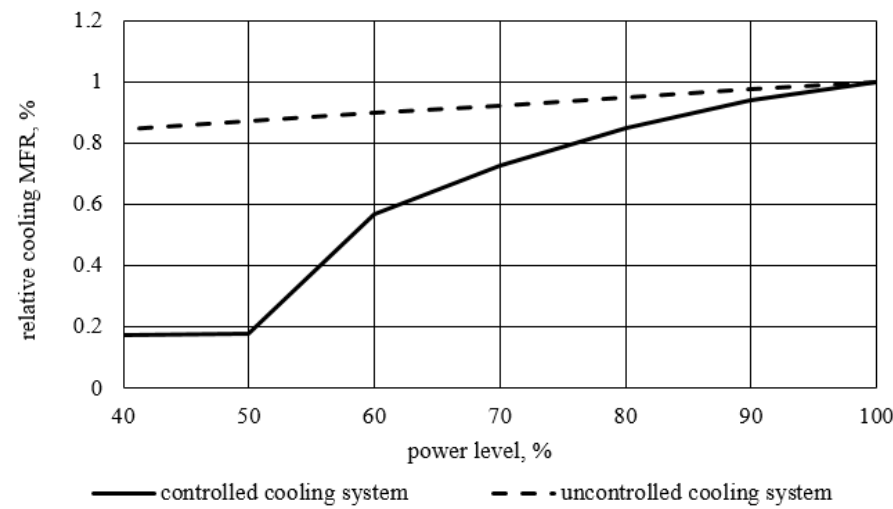

Fig. 9 - Relative cooling MFR vs GTU power level

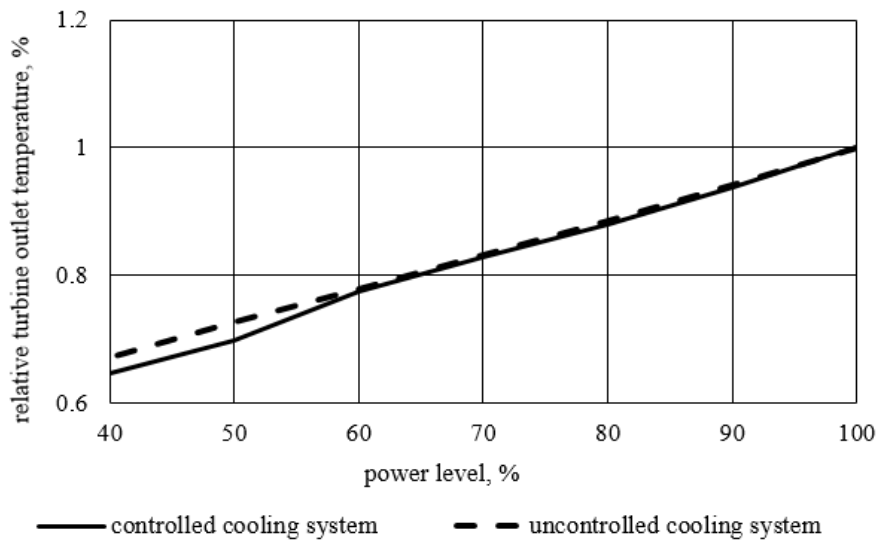

Fig. 10 - Relative turbine outlet temperature vs GTU power level 


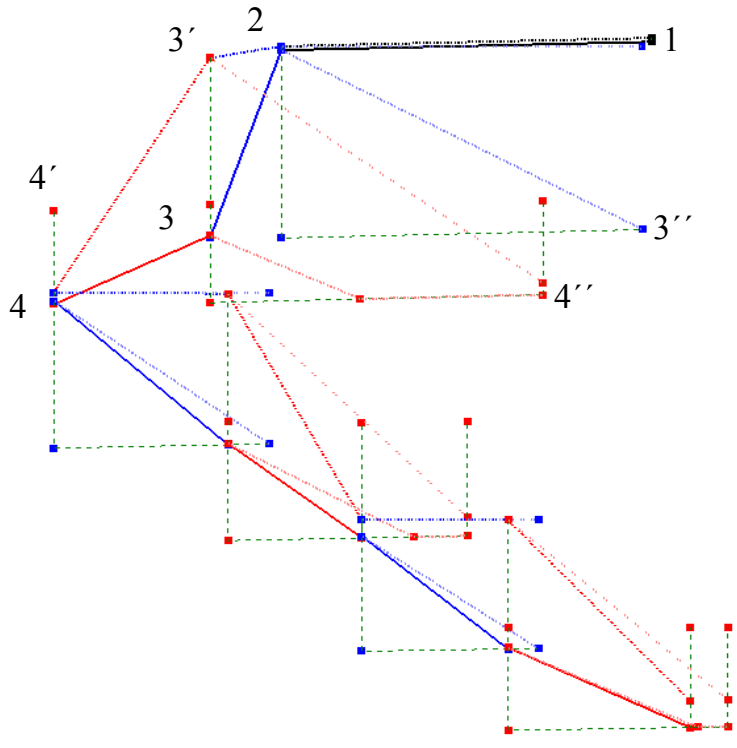

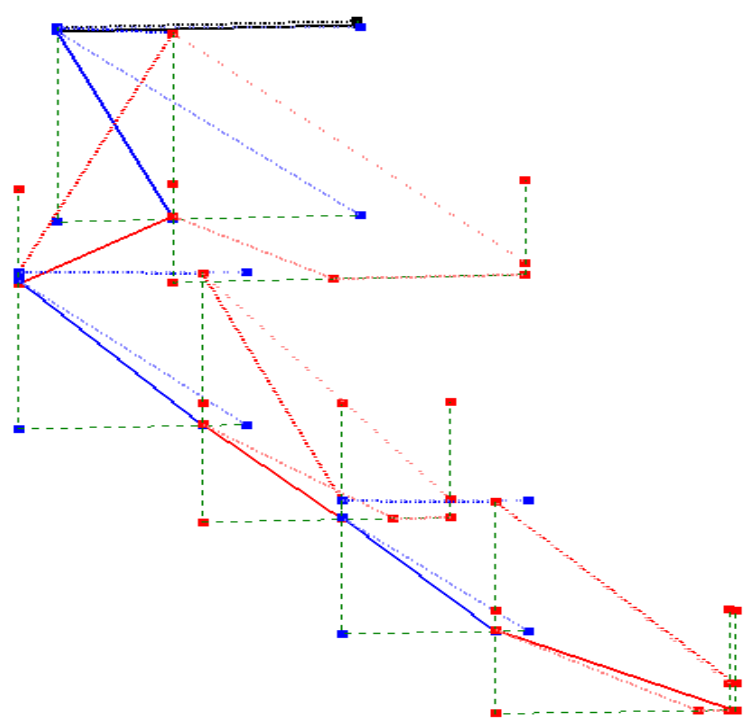

$b$

Fig. 11 - Expansion process of turbine in h-s diagram: $a$ - uncontrolled extraction; $b$ - controlled extraction;

blue lines are the nozzle expansion process; red lines are the blade expansion process; green verticals are isetropic expansion process; green inclined lines are isobars; dark lines are expansion process in duct.

As we can see the difference in turbine outlet temperature in the range $100-60 \%$ is not significant for controlled and uncontrolled cooling system types. The difference in $3 \%$ in relative values is observed when the main flow temperature is less than maximal allowable metal temperature and the cooling air MFR for stationary elements is equal to zero.

The proposed digital twin allows analyzing the internal aero-thermodynamic parameters at any row of compressor and turbine flow paths and cooling channels. This is an advantage of direct performance estimation comparing to map approach. As an example, Figure 11 represents the working fluid expansion process in the turbine taking into account cooling flows injections for both cases: controlled and uncontrolled cooling systems.

The explanation of the points and lines for the first stage of the turbine (Figure 11) is given below.

The 1-2 line represents the expansion process in the duct before turbine first stage.

Point 3 is the condition of gas after expansion in the first nozzle vane accounting cooling flows determined by static pressure, 3" - the same condition without cooling accounting. Point 3 ' shows the total parameters of working gas after expansion in the first nozzle.

Point 4 is the total parameters in the absolute frame after first blade row accounting the cooling flows, 4" - the same condition without cooling accounting. And the point $4^{\prime}$ show the parameters after first blade row in the relative frame.

The dotted lines show the process without cooling. The solid lines represent a real expansion process. Blue lines represent expansion processes in stationary nozzles. Red lines represent expansion processes in rotating blades.

\section{Approximate economics evaluation}

Preliminary economics analysis was performed assuming that the GTU works at $40 \%$ part-load mode from $20 \%$ to $50 \%$ of the time in a year. Thus, if the fuel price is equal to $\$ 0.17$ per $\mathrm{kg}$ of the fuel with LHV equal $50 \mathrm{~kJ} / \mathrm{kg}$, the savings may be from $\$ 154,000$ to $\$ 387,000$ per year.

\section{Conclusions}

- The developed GTUDT allows simulating the behavior of real GTU including off-design and partload modes, automatically calculating compressor, turbine and entire cooling system performance, and their matching.

- The validation of proposed GTUDT with the test data for the case of different ambient temperature values was done. The validation showed good agreement of the GTUDT performance data with the real test data.

- The assessment of the possibility of cooling mass flow rate control and its influence on turbine performance was performed. The efficiency increment at $40 \%$ of power is about $3.5 \%$ in relative values, at the $70 \%$, it is about $1 \%$. It should be noticed that cooling air MFR was controlled for first nozzle only. It can be assumed that the cooling air MFR controlling at another flow path elements allows getting even higher efficiency increments. 
- Preliminary economics analysis showed the savings are in the range from $\$ 154,000$ to $\$ 387,000$ per year. The final value of savings depends on part load mode power level and operation time percentage per year.

\section{Off-the-shelf software tools utilized in the study}

AxSTREAM ${ }^{\circledR}$ turbomachinery design, analysis and optimization tool $[12,13]$ was integrated into VGTU for simulation of compressor and turbine.

AxSTREAM NETTM 1D hydraulic networks analysis tool [14] was integrated into GTUDT for cooling system simulation.

AxSTREAM IONTM [15] system engineering infrastructure for the design of engineering systems was utilized for the development of GTUDT, including operation flowchart design, integration of the off-theshelf and custom software tools, and execution.

\section{Acknowledgments}

We wish to thank the many people from SoftInWay Inc. team who generously contributed their time and effort in the preparation of this work. The strength and utility of the material presented here are only as good as the inputs. Their insightful contributions are greatly appreciated.

\section{References}

1. Shnee J. I., Capinos V. M., Kotlar I. V., (1976), Gas turbines Thermodynamic processes heat exchanging in the designs, High School, Kyiv, 296 p.

2. El Hadik A. A. (1990), "The impact of atmospheric conditions on gas turbine performance", Journal of Engineering of Gas Turbine and Power, Vol. 112(4), pp. 590-596.
3. Ancona M. A., Bianchi M., Melino F. et al. (2015), "Power Augmentation Technologies: Part I - Literature Review", Proceedings of ASME Turbo Expo 2015: Turbine Technical Conference and Exposition, 2015, GT2015-43159.

4. Facchini B. (1993), "A simplified approach to off-design evaluation of single shaft heavy duty gas turbines", ASME CogenTurbo, IGTI, Vol. 8, pp. 189-197.

5. Wojciech Kosman. (2015), "Matching of a Gas Turbine and an Upgraded Supercritical Steam Turbine in Off-Design Operation", Journal of Power Technologies, No. 95(1), pp. 90-96.

6. Kurz Rainer, Brun Klaus. (2000), "Gas Turbine Performance What Makes The Map?", Proceedings of the $29^{\text {th }}$ turbomachinery symphosium, pp. 247-262.

7. Kaikko Juha. (1998), "Performance prediction of gas turbines by solving a system of non-linear equations", Thesis for the degree of Doctor of Technology, University of Technology, Lappeenranta, Finland on the 6th of March, $100 \mathrm{p}$

8. Janitha Kanishka Suraweera. (2011), "Off-Design Performance Prediction of Gas Turbines without the use of Compressor or Turbine Characteristics", Master of Applied Science In Aerospace Engineering, Carleton University Ottawa, Ontario, $254 \mathrm{p}$.

9. Moroz L., Govoruschenko Y., Pagur P. (2005), "Axial Turbine Stages Design: $1 \mathrm{~d} / 2 \mathrm{~d} / 3 \mathrm{~d}$ Simulation, Experiment, Optimization", Proceedings of ASME Turbo Expo 2005, Reno-Tahoe, Nevada, USA, GT2005-68614.

10. Ihor S. Diakunchak and David R. Nevin. (1989), "Site Performance Testing of CW251 B10 Gas Turbines", ASME, 89-GT$142,8 \mathrm{p}$.

11. Kholschevnikov K., Emin O., Mitrohin V. (1986), "Theory and calculation of the blade machines", Machine construction, 1986, pp. 267-267.

12. Moroz L., Govoruschenko Yu., Pagur P. (2006), "A uniform approach to conceptual design of axial turbine/compressor flow path", The Future of Gas Turbine Technology. 3rd International Conference, October 2006, Brussels, Belgium.

13. Moroz L., Govoruschenko Yu., Pagur P. (2005), "Axial turbine stages design: $1 \mathrm{~d} / 2 \mathrm{~d} / 3 \mathrm{~d}$ simulation, experiment, optimization", Proceedings of ASME Turbo Expo 2005, Reno-Tahoe, Nevada, USA, GT2005-68614

14. SoftInWay Inc. (2016), AxSTREAM NET TM user documentation.

15. SoftInWay Inc. (2017), AxSTREAM ION ${ }^{\mathrm{TM}}$ user documentation.

Received 05.02.2018

Відомості про авторів / Сведения об авторах / About the Authors

Мороз Леонід Ілліч (Мороз Леонид Іллич, Moroz Leonid) - кандидат технічних наук, директор, SoftInWay Inc., 1500 District Ave, Burlington, MA, USA, e-mail:1.moros@softinway.com.

Бурлака Максим Васильович (Бурлака Максим Васильевич, Burlaka Maksym) - кандидат технічних наук, провідний інженер, SoftInWay Inc., 1500 District Ave, Burlington, MA, USA, e-mail: m.burlaka@softinway.com.

Бараннік Валентин Сергійович (Баранник Валентин Сергеевич, Barannik Valentyn) - кандидат технічних наук, інженер, SoftInWay Inc., 1500 District Ave, Burlington, MA, USA, e-mail: v.barannik@softinway.com; ORCID: https://orcid.org/0000-0002-1472-0143. 